\title{
Islet Endocrine-Cell Behavior From Birth Onward in Mice With the Nonobese Diabetic Genetic Background
}

\author{
Carme Pelegri, ${ }^{1,3}$ Judith G.M. Rosmalen, ${ }^{2}$ Sylvie Durant,, ${ }^{1}$ Marc Throsby, ${ }^{1}$ Véronique Alvès, ${ }^{1}$ Josiane \\ Coulaud, ${ }^{1}$ Anne Esling, ${ }^{4}$ Jean-Marie Pléau, ${ }^{1}$ Hemmo A. Drexhage, ${ }^{2}$ and Françoise Homo-Delarche ${ }^{1}$ \\ ${ }^{1}$ CNRS UMR 8603, University of Paris V, Necker Hospital, Paris, France \\ ${ }^{2}$ Department of Immunology, Erasmus University, Rotterdam, The Netherlands \\ ${ }^{3}$ Departament de Fisiologia-Divisió IV, Facultat de Farmàcia, Universitat de Barcelona, Spain \\ ${ }^{4}$ Centre de l'Association Claude Bernard sur les Maladies Autoimmunes, Necker Hospital, Paris, France \\ Accepted January 31, 2001
}

\begin{abstract}
Background: Glucagon-producing $\alpha$ cells play a crucial role during the perinatal period. Because of their peri-islet localization near the early dendritic and macrophage cell infiltration, we thought it pertinent to investigate $\alpha$ cells in greater depth in nonobese diabetic (NOD) mice, a wellrecognized spontaneous model for human type I diabetes. Materials and Methods: We determined $\alpha$-cell distribution (glucagon immunohistochemistry and image analysis) and activity (real-time reverse transcriptase polymerase chain reaction [RT-PCR] and glucagon radioimmunoassay [RIA]), in relationship to glycemia in NOD and lymphocyte-deficient NODscid mice as compared to control mice (C57BL/6) from birth onward.

Results: NOD and NODscid mice, particularly at 1 day of age, had twice as many very small islets $(<2000$ pixels $)$ as C57BL/6 mice. During the postnatal period, the percent-
\end{abstract}

ages of glucagon-positive areas in islets less than 2000 pixels were higher in NOD mice than C57BL/6; only a trend was found in NODscid. Pancreatic mRNA expression and glucagon content decreased in all strains at weaning. However, before weaning, pancreatic and blood glucagon levels were significantly lower in NOD and NODscid compared to C57BL/6 mice. Low basal nonfasting glycemia was observed in all strains before weaning with some strain differences: glycemia was significantly lower in NOD than C57BL/6, and higher in NODscid than NOD and C57BL/6. Conclusion: These data suggest that, before weaning, NOD and, to some extent NODscid pancreata contain more immature islets (as reflected by their small size and high percentages of glucagon-positive areas, concomitant with lower glucagon storage and basal secretion) than C57BL/6 pancreata.

\section{Introduction}

Despite extensive genetic and immunologic research, the complex etiology and pathogenesis of type I diabetes remain unexplained (1). In addition to investigations in humans, two spontaneous animal models of the disease have been helpful in these studies, namely the bio-breeding rat and the nonobese diabetic (NOD) mouse $(2,3)$. In all cases, type I diabetes is a polygenic disease, with multiple defects in various immune cell types $(2,3)$. However, these immune dysfunctions cannot explain the organ specificity of the autoimmune process. It has been suggested that abnormalities in the islet itself may play an important role in the breakdown of tolerance toward islet $\beta$ cells $(4,5)$.

In our search for such prediabetic islet anomalies, we demonstrated a rather surprising but transient $\beta$-cell hyperactivity in prediabetic 4 - to 8week-old NOD mice (6). Indeed, we observed, starting after weaning, which normally takes place

Address correspondence and reprint requests to: Françoise Homo-Delarche, CNRS UMR 8603, Hôpital Necker, 161, rue de Sèvres, 75015 Paris, France. Phone: Tel: 33-1-44495388; Fax: 33-1-44490676. E-mail: fhomodel@wanadoo.fr at about 3 weeks of age in mice, higher insulin levels and lower glycemia values, particularly in NOD females, as compared to mice from various control strains $(5,7)$. Both parameters were also shared to some extent by the NODscid/scid (NODscid) mouse (5), which lacks functional lymphocytes and therefore does not develop lymphocytic insulitis or diabetes (8). It is worth noting here that hyperinsulinemia in NOD and NODscid mice appears at weaning, a normal period of $\beta$-cell stimulation even in normal rodents because of dietary changes from low carbohydrate maternal milk to high carbohydrate laboratory chow (5).

Other postweaning islet abnormalities have also been described, such as higher percentages of adult $\beta$ stem cells $\left(\mathrm{SOM}^{+} / \mathrm{PDXI}^{+}\right)$in 4 -week-old NOD mice, compared to control ICR mice $(40 \%$ versus $10 \%$, respectively) (9). Moreover, the numbers of these $\beta$ stem cells increased thereafter in parallel with the peri-islet mononuclear infiltration. It should be noted here that, in NOD and NODscid mice, the first sign of the disease consists of early islet infiltration by various types of dendritic cells and macrophages, which intriguingly also occurs around the time of weaning at the islet periphery where endocrine non- 
$\beta$ cells (i.e., $\alpha, \delta$, and pancreatic polypeptide cells) are located $(5,10,11)$.

With regard to the latter endocrine non- $\beta$ cells, glucagon-producing $\alpha$ cells play an important role during the perinatal period. First, prenatally, $\alpha$ cells are the most numerous endocrine cell type, accounting for over $2 \%$ of the total pancreatic mass at 16 days of gestation in rat fetuses (12). By birth, the differential growth rates of the various endocrine cells result in a predominance of $\beta$ cells, leading to a decreased $\alpha / \beta$ ratio, while the glucagon content per $\alpha$ cell increases sharply (13). Moreover, in normal rodents, pancreatic glucagon contents and glucagonemia are known to be elevated during the neonatal period and to decline drastically thereafter (12-16). In parallel, proglucagon mRNA levels were also shown to be higher between El7 prenatally and days 10-14 postnatally than in adult rats (17). Physiologically, hyperglucagonemia, immediately after birth, is considered to be an adaptative mechanism to counterbalance the normally occurring neonatal hypoglycemia $(14,15)$. Finally, with regard to type 1 diabetes, although there is some evidence that $\alpha$ cells themselves might also be a target, they appear to be spared from autoimmune destruction (18-21).

Because of their peripheral localization and their crucial role from birth onward, we thought it relevant to explore in greater depth $\alpha$ cells in NOD mice, particularly during the early postnatal period. In this regard, we determined $\alpha$-cell distribution and activity in relationship to glycemia in mice with the NOD genetic background (NOD and NODscid) as compared to control mice (C57BL/6) as a function of age. To distinguish between the events that can be induced or not by lymphocytes, NODscid mice, which lack functional lymphocytes, were also used because they share with NOD mice part of the early peri-islet immune dendritic cell/macrophage and endocrine abnormalities, but do not progress to insulitis and diabetes $(5,11,22)$.

\section{Materials and Methods}

Mice

NOD, originally provided by Clea Japan Inc. (Tokyo, Japan), NODscid, and C57BL/6 females were bred at the animal facilities of Hôpital Necker, Paris, France, under specific pathogen-free conditions and handled, according to the norms stipulated by the European Community. They were antibody free for the 13 viruses tested, including diabetogenic viruses (23). Mice were fed standard pellets and water ad libitum and maintained at $22 \pm 1^{\circ} \mathrm{C}$ on a 12-hr light-dark cycle. All strains were weaned during the third week of life. Nondiabetic NOD females (with basal nonfasting glycemia $<11 \mathrm{mmol} / \mathrm{l}$, as assessed by Glukotest, Boehringer-Mannheim, Mannheim, Germany) were used. In our NOD colony, during the time of this investigation, overt diabetes appeared in females from the $12^{\text {th }}$ week of age onward and $80 \%$ became diabetic by 6 months of age.

\section{Immunohistochemistry Samples}

Six pancreata for each strain were removed at 1,7 , $14,21,28,56$, and 70 days of age. After excision, they were immediately embedded in OCT (Tissue-Tek ${ }^{\circledR}$, Miles, Elkart, IN, USA), frozen in dry ice-cooled isopentane and stored at $-80^{\circ} \mathrm{C}$ until sectioning. Cryostat sections, $6-\mu \mathrm{m}$ thick, were cut, dried overnight and frozen at $-20^{\circ} \mathrm{C}$ until being subjected to labeling. Tissues used for double-labeling experiments were fixed in Bouin's solution (Sigma, SaintQuentin-Fallavier, France) and paraffin embedded; $4-\mu \mathrm{m}$ thick sections were cut.

\section{Immunohistochemistry Protocol}

Sections were prepared from central regions of the pancreas that included sufficient numbers of islets. Sections were allowed to thaw at room temperature for $30 \mathrm{~min}$. After being fixed in acetone for $10 \mathrm{~min}$, slides were washed in phosphate-buffered saline (PBS) $0.05 \%$ Tween 20 (Tw). Sections were incubated with prediluted rabbit anti-human glucagon (Dako, Trappes, France) for $30 \mathrm{~min}$. After washing in PBS-Tw, sections were incubated with the secondary antibody, biotinylated swine anti-rabbit Ig (Dako), diluted 1/100, for $30 \mathrm{~min}$. After rinsing in PBS-Tw, Avidin-Biotin Complex (Vectastain kit, Vector, Burlingame, CA, USA) was added for $20 \mathrm{~min}$. After further washing, the bound complex was developed with 3-amino-9-ethyl-carbazole (Sigma) in $50 \mathrm{mM}$ sodium acetate. After $2.5 \mathrm{~min}$, the reaction was stopped with distilled water. After rinsing in PBS-Tw, sections were counterstained with Mayer's hemalum solution (Merck, Paris, France) and mounted in Faramount aqueous mounting medium (Dako). Negative controls were performed with reagents supplied by Dako.

Double labeling was performed on $4-\mu \mathrm{m}$ sections cut from paraffin-embedded tissues. After dewaxing and rehydration, the tissues were washed in Trissaline buffer (0.1 M Tris- $\mathrm{HCl}, \mathrm{pH} 7.5,0.15 \mathrm{M} \mathrm{NaCl}$, $0.05 \% \mathrm{Tw})$. Sections were incubated with optimally diluted guinea pig anti-insulin serum (Linco Research Inc., St. Charles, MO, USA) and rabbit anti-glucagon serum (Chemicon International Inc., Temecula, CA, USA) overnight at $4^{\circ} \mathrm{C}$. Slides were thoroughly washed in Tris-saline buffer and incubated first with alkaline phosphatase-conjugated swine anti-rabbit IgG (Dako) for $30 \mathrm{~min}$ at room temperature, rinsed, and then incubated with rabbit anti-guinea pig IgG coupled to horseradish peroxidase (Dako) for a further $30 \mathrm{~min}$. Sections were rinsed first in Trissaline buffer ( $\mathrm{pH} 7.5)$, then briefly in alkaline Trissaline buffer ( $\mathrm{pH} 9.5$ containing $50 \mathrm{mM} \mathrm{MgCl}_{2}$ ). Immunoreactive glucagon was revealed using a substrate consisting of $0.34 \mathrm{mg} / \mathrm{ml}$ of nitroblue tetrazolium chloride (Boehringer-Mannheim) and 0.18 $\mathrm{mg} / \mathrm{ml}$ of 5-bromo-4-chloro-3-indolyl phosphate (Research Organics Inc., Cleveland, OH, USA). Slides were protected from light and periodically 
checked for staining intensity. The reaction was stopped by returning sections to neutral $\mathrm{pH}$ in Trissaline buffer containing $10 \mathrm{mM}$ EDTA. Slides were washed thoroughly for at least $30 \mathrm{~min}$, then reacted with the peroxidase chromogen diaminobenzidine (Sigma) in PBS with $0.02 \% \mathrm{H}_{2} \mathrm{O}_{2}$ for $1-2$ min. Slides were finally rinsed in water, counterstained with methyl green (Fluka, Buchs, Switzerland), progressively dehydrated through alcohol baths, cleared, and mounted.

\section{Morphometric Analyses}

All islets from each glucagon-labeled section were considered. The area of each islet was measured using a VIDAS-RT image analysis system (Kontron Elektronik GmbH/Carl Zeiss, Weesp, The Netherlands). The counterstaining enabled easy identification of the islets, which were encircled by hand and then the computer program automatically calculated the area of each islet in pixels, and determined the glucagon-positive area and the percentage of glucagon-positive area of each islet. Measurements were made at a magnification of $100 \times$, at which the size of one pixel is $1.13 \times 10^{-6} \mathrm{~mm}^{2}$.

For the analysis of some data, islets were arbitrarily classified into various groups according to their size: very small (area $<2000$ pixels), small (between 2000 and 5000 pixels), medium (between 5000 and 10,000 pixels) and large (>10,000 pixels). The percentages of glucagon-positive areas were then determined for each class of islets.

The total number of islets was counted for a strain at a given age (one section per mouse and per age, $n=6$ mice for each age group of a given strain). The total numbers of islets were: on day 1, 78-95; day 7, 119-154; day 14, 119-181; day $21,138-175$; day 28, 85-110; day 56, 68-102; and day 70 100-203. Only one section of each pancreas was measured to ensure that an individual islet was not measured more than once.

\section{RT-PCR for Proglucagon}

The pancreatic expression of mRNA encoding for proglucagon was established using real-time reverse transcriptase polymerase chain reaction (RT-PCR) methodology. Briefly, total RNA was extracted from mouse pancreata using Trizol (Life Technologies, Cergy-Pontoise, France) according to the manufacturer's instructions. After reverse transcription of 2 $\mu \mathrm{g}$ of total RNA in a final volume of $20 \mu \mathrm{l}$ in the presence of oligo (dT) 15 and hexamer random primer using the reverse transcription system from Promega (Charbonnières, France), PCR was performed, using the ABI PRISM 7700 sequence detection system (Perkin-Elmer France, Courtaboeuf, France), in a total volume of $25 \mu \mathrm{l}$, containing $1 \mu \mathrm{l}$ of cDNA sample or standard containing $10^{3}$ to $10^{6}$ specific glucagon cDNA copies, $20 \mathrm{mM}$ Tris $\mathrm{HCl}(\mathrm{pH}$ 8.3 ), $50 \mathrm{mM} \mathrm{KCl}, 60 \mathrm{nM}$ passive reference (ROXAGTTGG), $200 \mu \mathrm{M} \mathrm{dNTP,} 5 \mathrm{mM} \mathrm{MgCl}_{2}, 100 \mathrm{nM}$ each primer, $100 \mathrm{nM}$ specific probe, and $0.5 \mathrm{U}$ of Taq platinium DNA polymerase from Life Technologies. Primers (forward 5'TGGCAGCACGCCCTTC $3^{\prime}$ and reverse 5'GCGCTTCTGTCT-GGGA $3^{\prime}$ ) and probe (TET-AGACACAGAGGAGAACCCCAGATCATTCCTAMRA) were designed using the computer program Primer express and used after HPLC purification.

Each PCR amplification was run in triplicate, under the following conditions: $2 \mathrm{~min}$ at $50^{\circ} \mathrm{C}$ and $10 \mathrm{~min}$ at $94^{\circ} \mathrm{C}$, followed by a total of 45 cycles of two temperature steps $\left(30 \mathrm{sec}\right.$ at $95^{\circ} \mathrm{C}$ and $1 \mathrm{~min}$ at $60^{\circ} \mathrm{C}$ ). To compensate for the variation between RNA preparations and reverse transcription efficiency, an endogenous "housekeeping" gene (GAPDH) was also amplified using the Perkin-Elmer kit and results were normalized to these values. The standard curve was established by plotting the cycle threshold $\left(C_{\mathrm{T}}\right)$ values against the $\log _{10}$ number of RNA copies present in each standard. The results are expressed as the number of mRNA copies per pg of total mouse pancreatic RNA.

\section{Measurement of Blood and Pancreatic Glucagon}

In all cases, unanesthetized animals were bled in less than 2 min by retro-orbital puncture. As previously shown, this technique avoids stress-induced metabolic changes (24). In each series of experiments, different groups of animals of various ages $(7,14$, $28,42,56$, and 70 days old) were bled at different times to avoid the hyperglycemic effect of repeated orbital puncture (24). Blood samples were supplemented with recombinant aprotinin, 30,000 kIU/ml (Bayer Inc., Kankakee, IL, USA), kept on ice, centrifuged at $13,000 \times \mathrm{g}$ for $2 \mathrm{~min}$ at $4^{\circ} \mathrm{C}$, and stored at $-20^{\circ} \mathrm{C}$. After bleeding, mice were immediately killed by cervical dislocation. Pancreata were rapidly removed, weighed, and homogenized in $15 \mathrm{ml}$ of cold acid ethanol extraction medium (1.5\% [v/v] $1 \mathrm{~N}$ $\mathrm{HCl}$ in $75 \%$ ethanol). After addition of another 10 $\mathrm{ml}$ of extraction medium, the homogenates were centrifuged $\left(800 \times \mathrm{g}\right.$ for $15 \mathrm{~min}$, at $\left.4^{\circ} \mathrm{C}\right)$, and the supernatants were left standing overnight at $4^{\circ} \mathrm{C}$. The $\mathrm{pH}$ of the supernatants was adjusted to 8.5 with ammonium hydroxide and, after centrifugation $(800 \times \mathrm{g}$ for $15 \mathrm{~min}$, at $\left.4^{\circ} \mathrm{C}\right), 5 \mathrm{ml}$ of each supernatant were stored at $-20^{\circ} \mathrm{C}$ until assayed. Glucagon concentrations were determined using a standard radioimmunoassay (RIA) kit (rabbit anti-human glucagon, Biodata, Pharmacia, Saint-Quentin-en-Yvelines, France). Pancreatic glucagon contents are expressed as ng/mg of pancreas, as commonly used $(13,25,26)$.

\section{Glycemia, Insulinemia, and Corticosterone Determinations}

Glucose concentrations were measured using the glucose oxidase method (Biotrol glucose enzymatic color, Biotrol, Paris, France). Plasma insulin concentrations were determined using a standard RIA (SBinsulin-CT, CIS Biointernational, Gif-sur-Yvette, France). Plasma corticosterone was assessed with the ICN RIA kit (Sorin Biomedica, Antony, France). 


\section{Statistical Analyses}

All data are expressed as means \pm SEM. Possible effects of strain and age were analyzed using ANOVA for each variable investigated. Post hoc analysis, using the Newman-Keuls test, was performed when effects and interactions were significant $(p<0.05)$, as assessed by ANOVA. When the interaction was not significant, planned comparisons were made.

\section{Results}

Both NOD and NODscid Mice Have More Very Small Islets than C57BL/6 Mice During the Early Postnatal Period

We first examined islet $\alpha$-cell characteristics combining glucagon immunohistochemistry and image analysis to quantify the data. An example of the immunohistochemical data obtained in pancreata from 7-day-old female C57BL/6 and NOD mice is given in Figure 1. Figure 1A shows a pancreas section from a C57BL/6 mouse stained for insulin (brown) and glucagon (blue). At this age, in the control C57BL/6 strain, the few glucagon-positive $\alpha$ cells are most frequently located at the periphery of large islets surrounding the $\beta$-cell core, a pattern typical of a mature islet with a low $\alpha / \beta$ cell ratio $(12,16)$. In contrast, sections of age-matched female NOD pancreata (Fig. 1B,C) show small clusters of glucagonpositive $\alpha$ cells (arrows), which only occasionally contain insulin-positive $\beta$ cells. In addition, in NOD mice, many small islets are observed that seem to have a large proportion of glucagon-positive $\alpha$ cells around the periphery of the $\beta$-cell core, a pattern characteristic of a high $\alpha / \beta$ cell ratio (Fig. ID).

Figure $2 \mathrm{~A}$ shows that the mean islet surface area assessed using glucagon immunohistochemistry
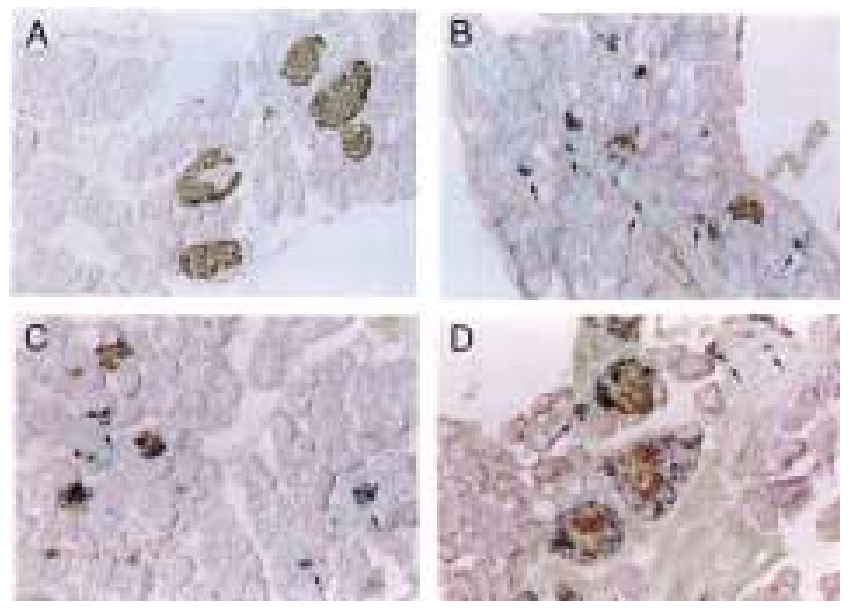

Fig. 1. Sections of 7-day-old female C57BL/6 (A) and NOD (B-D) mouse pancreata stained for immunoreactive glucagon (blue) and insulin (brown) (magnification A-C: $320 \times$ and $D: 500 \times$ ). Small glucagon-positive islets (arrows) are present throughout the tissue of NOD (B-D) but not C57BL/6 mice (A). Many insulin-containing islets in NOD mice have unusually large proportions of glucagon-positive $\alpha$ cells at their periphery (D), as compared to age-matched C57BL/6 (A).
A

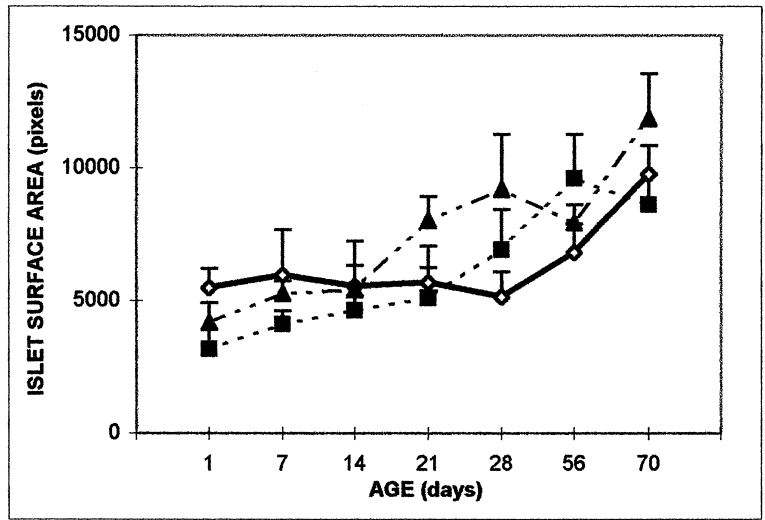

B

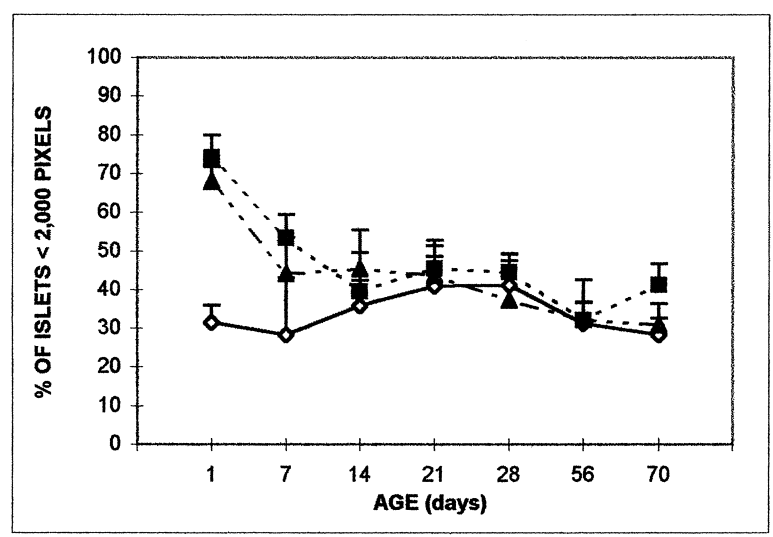

Fig. 2. Islet surface areas in C57BL/6 $(\bigcirc)$, NOD (ם) and NODscid $(\Delta)$ females as a function of age $(A)$ and frequency of very small islets $(<2000$ pixels) $(B)$. Values are expressed as means \pm SEM $(n=6 /$ age/strain $)$.

increased significantly with age in all strains $(p<0.001$ by ANOVA): preweaned mice have smaller islets than postweaned mice. To analyze further the islet distribution in the various strains, we arbitrarily classified these islets based on their size: $<2000$ pixels (very small), 2000-5000 pixels (small), 5000-10,000 pixels (medium), and $>10,000$ pixels (large). The striking finding was that both NOD and NODscid mice had, on a percentage basis, twice as many very small islets $(<2000$ pixels $)$ as C57BL/6 mice at birth $(p<0.001)$ (Fig. 2B). A significant difference between strains was still observed at 7 days $(p<0.05)$, but had disappeared by 14 days. However, no significant difference was observed between strains for the percentages of small islets (2000-5000 pixels).

\section{NOD Mice Have Higher $\alpha / \beta$ Cell Ratios in Their Islets than C57BL/6 Mice from Birth Onward, Especially in Very Small and Small Islets}

We then determined the percentage of islet areas that contained glucagon-producing $\alpha$ cells in all islets from C57BL/6, NOD, and NODscid mice as a function of age, regardless of their size (Fig. 3A). Considering all ages together, the percentages of glucagon-positive areas in all islets were significantly higher in NOD 

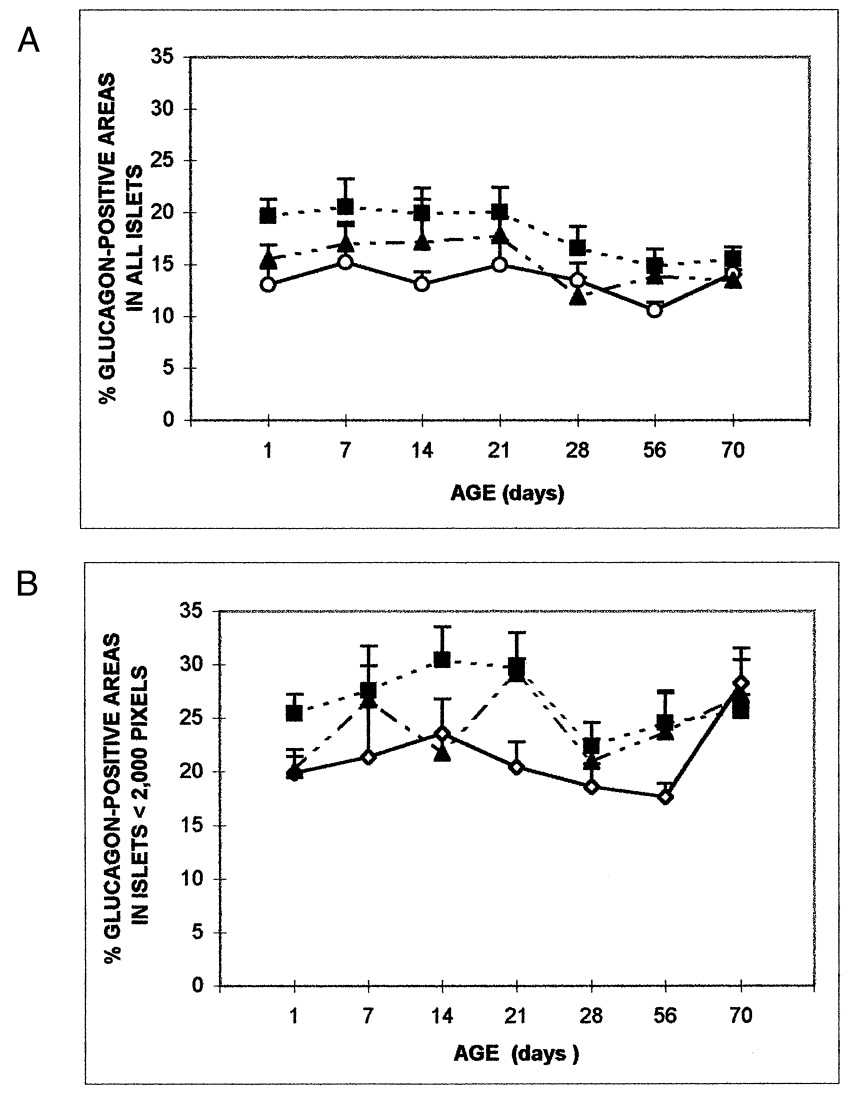

Fig. 3. Glucagon-positive areas given as percentages of total islet area in all islets $(A)$ and in very small islets

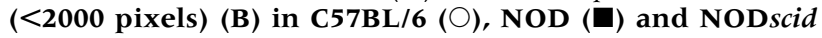
$(\triangle)$ females as a function of age. Values are expressed as means $\pm \operatorname{SEM}(n=6 /$ age $/$ strain $)$.

than in C57BL/6 $(p<0.001)$ and NODscid $(p<0.01)$ mice (with NOD and NODscid mice being comparable). When comparing NOD and C57BL/6 mice at a given age, the percentages of glucagon-positive areas in islets were significantly higher in NOD mice only before weaning: $(p<0.05$ at 1 and 14 days of age) and tended toward significance $(p<0.07)$ at 7 and 21 days of age.

The percentages of glucagon-positive areas were then calculated separately for the different islet size classes. Figure 3B shows that, when considering all ages together, NOD mice had significantly higher percentages of glucagon-positive areas in the very small islets compared to C57BL/6 mice $(p<0.01)$, whereas NODscid mice only showed a trend toward significantly higher values compared to C57BL/6 mice $(p=0.076)$. However, NOD and NODscid mice did not differ significantly concerning the percentages of glucagon-positive areas in the very small islets. NOD mice also had higher percentages of glucagon-positive areas compared to C57BL/6 mice in small islets (2000-5000 pixels) $(p<0.001)$, but not in islets $>5000$ pixels (results not shown).

\section{All Strains Have High Pancreatic Proglucagon mRNA Contents Before Weaning}

We then compared proglucagon synthesis in the three strains. The patterns of proglucagon mRNA expression varied significantly with age $\left(p<10^{-5}\right.$ by ANOVA). The most striking observation was its decrease between days 14 and 28 (i.e., around weaning), which was significant in C57BL/6 and NOD mice $(p=0.02$ and $p=0.03$, respectively) (results not shown). This decreased pancreatic proglucagon mRNA expression around weaning is due to the marked growth of pancreatic tissue, particularly the exocrine compartment, and confirms previous Northern blot data obtained in the rat (17). However, no significant strain difference was observed during the early postnatal period.

\section{NOD and NODscid Mice Have Low Pancreatic Glucagon Contents Before Weaning Compared to C57BL/6 Mice}

Like proglucagon mRNA, due to the marked growth of the pancreas postnatally, stored glucagon contents, expressed in Figure 4 as ng of glucagon $/ \mathrm{mg}$ of pancreas, were significantly decreased in all strains after weaning as compared to before weaning $(p<$ $10^{-4}$ for C57BL/6 and NODscid, and $p<0.05$ for NOD mice). Moreover, although there was no significant difference in relative pancreatic stored glucagon amounts between the three mouse strains after weaning, a difference between control and NOD strains was observed before weaning: 7-day-old C57BL/6 mice had significantly higher pancreatic glucagon contents than age-matched NOD $\left(p<10^{-4}\right)$ and NODscid $(p<0.05)$ mice. At 14 days of age, the difference between C57BL/6 and NODscid mice was still significant $(p<0.01)$.

NOD and NODscid Blood Glucagon Levels Are Lower Before Weaning Compared to C57BL/6 Mice

Figure 5 shows circulating basal nonfasting glucagon levels as a function of age in the three strains. Although

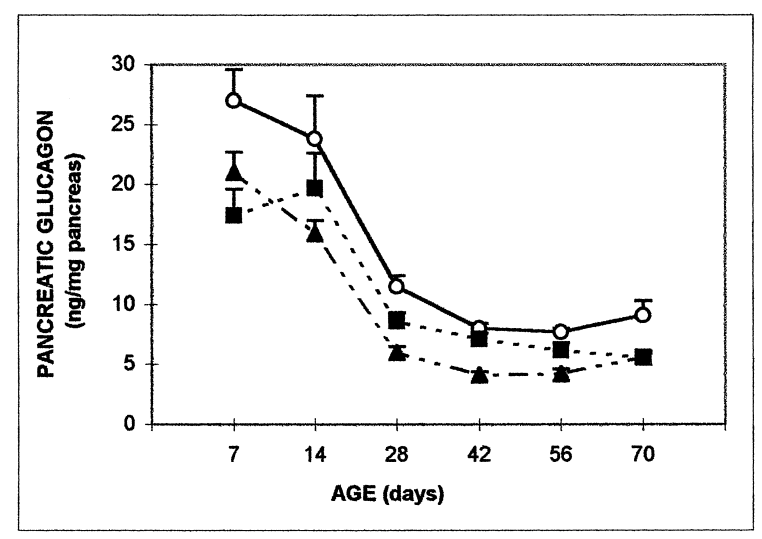

Fig. 4. Pancreatic glucagon contents in C57BL/6 $(\bigcirc)$, NOD $(\square)$ and NODscid $(\boldsymbol{\Delta})$ females as a function of age. Values are expressed as means \pm SEM $(n=15 /$ age/strain $)$. 


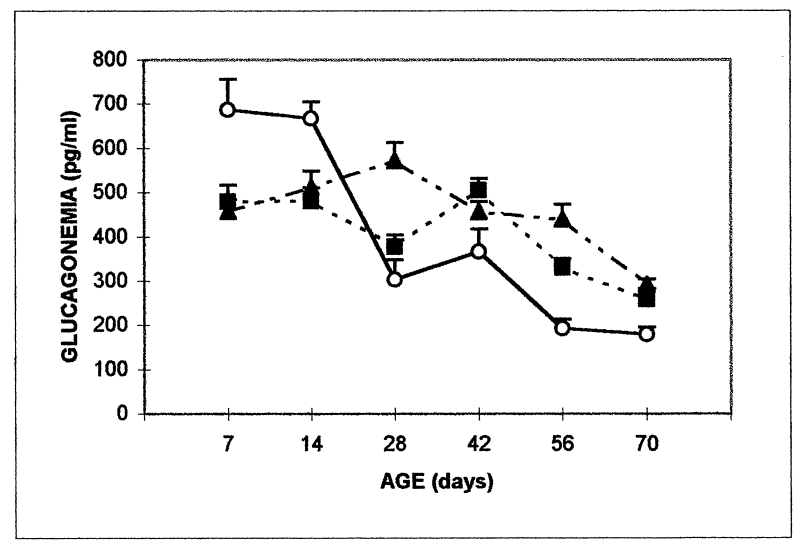

Fig. 5. Basal nonfasting blood glucagon levels in C57BL/6 $(O)$, NOD ( $\square)$ and NODscid $(\Delta)$ females as a function of age. Values are expressed as means \pm SEM $(n=15 /$ age/strain $)$.

glucagon levels decreased with age in all strains, the patterns of decrease differed between the strains with the NOD genetic background and the control strain (C57BL/6). In C57BL/6 mice, as was already described for normal rodents $(12,14-16)$, glucagon levels were relatively high before weaning and declined significantly thereafter. In particular, glucagon levels in C57BL/6 mice at 7 or 14 days of age were significantly higher than those found at later times $\left(p<10^{-4}\right)$ : the most significant decline was observed between days 14 and 28 of age in close relationship to weaning. In NOD and NODscid mice, a decrease of blood glucagon concentrations was also observed with age, but it was delayed and less marked when compared to that in C57BL/6 mice.

These different kinetics of blood glucagon concentrations in NOD and NODscid mice were the reflection of differences in circulating glucagon levels at a given age. Before weaning, on days 7 and 14, blood glucagon concentrations were significantly higher in C57BL/6 than in NOD $(p<0.01)$ and NODscid $(p<0.05)$ mice. By contrast, after weaning, glucagon concentrations in NOD and NODscid were consistently higher than those in C57BL/6 mice, with differences reaching significance at some times, in particular on days 28 and $56\left(p<0.05\right.$ and $10^{-4}$, respectively).

\section{Basal Glycemia Differs Before and After \\ Weaning in all Three Strains}

Finally, we measured basal blood glucose levels in all strains as a function of age, because of the counterregulatory effects of glucagon, which is of crucial importance during the neonatal period. Figure 6 shows the striking effect of age on basal nonfasting glycemia in the three strains $\left(p<10^{-6}\right.$, as assessed by ANOVA): basal glucose levels were, as expected, low before weaning in all strains and increased sharply thereafter. Strain differences were also observed before and after weaning. Intriguingly, before weaning, NODscid mice had significant higher

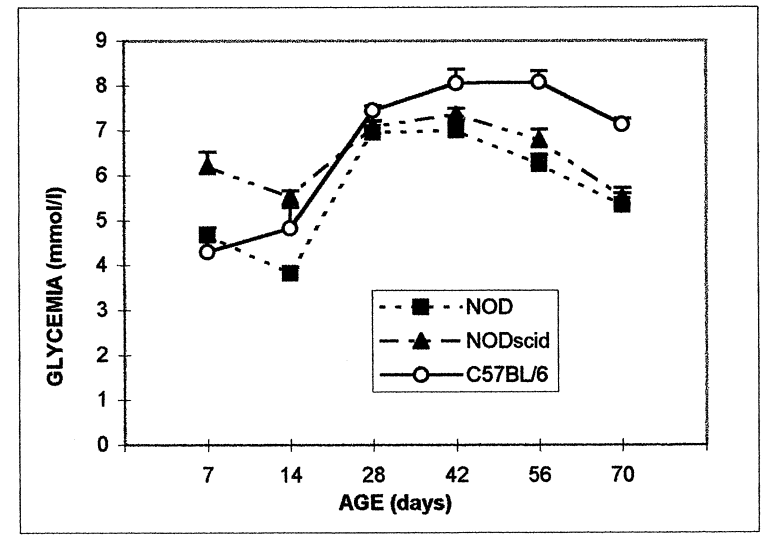

Fig. 6. Basal nonfasting glycemia in C57BL/6 (O), NOD (ם) and NODscid $(\Delta)$ females as a function of age. Values are expressed as means \pm SEM $(n=15 /$ age/strain $)$.

basal glycemia than C57BL/6 at 1 week of age ( $p=$ $0.00005)$, and NOD at 1 and 2 weeks of age ( $p$ values from 0.0002-0.00005). Moreover, at 2 weeks of age, when glucagon levels were significantly lower, NOD mice also had significantly lower basal glycemia than C57BL/6 mice $(p=0.025)$. At this age, we also measured basal insulin and corticosterone concentrations in individual mice. Corticosterone levels did not differ significantly between strains (varying from 29.6 to $59 \mathrm{ng} / \mathrm{ml}, n=$ $12 \mathrm{mice} /$ strain), reflecting unstressed levels (24). However, a strain difference was observed in basal insulinemia: NODscid mice had significantly higher insulin levels $(112.5 \pm 11.2 \mathrm{pmol} / \mathrm{l})$ than $\mathrm{C} 57 \mathrm{BL} / 6$ (72.4 $\pm 5 \mathrm{pmol} / \mathrm{l})$ and NOD mice $(86 \pm 4.1 \mathrm{pmol} / \mathrm{l})$ $(p=0.002$ and 0.02 respectively, $n=15$ in each group).

\section{Discussion}

The data presented illustrate several differences in islet endocrine cell behavior between mice with the NOD genetic background and control C57BL/6 mice, particularly before weaning. The most conspicuous difference was the presence in 1- and 7-day-old NOD and NODscid mice of high numbers of very small islets with relatively enhanced $\alpha / \beta$ cell ratios, especially in NOD mice. Moreover, the presence of these small-sized islets is associated, during the early postnatal period, with rather high proglucagon mRNA expression, but low pancreatic glucagon stores and low basal glucagonemia. Taken together, these features suggest the presence of immature islets and early disturbances of islet development in mice with the NOD genetic background.

These immature islets, possibly reflecting increased islet neogenesis, might accompany the first wave of $\beta$-cell hyperactivity that we recently described at birth in NOD mice, based on the high levels of preproinsulin 2 primary transcript expression in the pancreas (7). Islet neogenesis from duct epithelial 
cells occurs during embryonic development and very early postnatal life $(16,27)$. Islet development and/or regeneration is characterized by increased numbers of small islets and frequent connections between islets and ducts (28-30). Indeed, we frequently observed these connections in the three mouse strains investigated during the early postnatal period. Moreover, even in control strains, various types of macrophages were repeatedly located around the ducts and islets and also between these structures, as if they were involved in tissue remodeling taking place during normal postnatal islet neogenesis. The only thing differing in NOD strains was the numbers of macrophages recovered on pancreatic sections (manuscript submitted).

In normal rodents, proglucagon mRNA levels, pancreatic glucagon contents, and basal glucagonemia are known to be high during the neonatal period and to decline sharply thereafter (13-17). Accordingly, basal glucagonemia was elevated before weaning in control C57BL/6 mice. However, during the same period, it was significantly lower in mice with the NOD genetic background than in C57BL/6 mice. Hyperglucagonemia immediately after birth is considered to be an adaptive mechanism to counterbalance normally occurring neonatal hypoglycemia. We confirmed low basal nonfasting blood glucose levels in all strains before weaning, but some strain differences were observed. First, 2-week-old NOD mice had lower basal glycemia than C57BL/6 controls but similar insulinemia, in good relationship to their respective glucagonemia levels. Second, NODscid mice showed an unexpected pattern of higher basal glycemia than the two other strains before weaning, with higher insulinemia but low glucagonemia. To the best of our knowledge, it is presently unknown whether abnormalities of glucose homeostasis exist in mice with the scid mutation. However, it is worth noting here that nude BALB/c mice, which are deprived of thymus, have several endocrine anomalies including impaired glucose tolerance at very young age and peripheral insensitivity to insulin $(31,32)$.

Later (i.e., after weaning) NOD and NODscid mice experienced relative hyperglucagonemia, thereby confirming the results obtained by others (33). We also observed in in vitro culture of islets of Langerhans from 8-week-old NOD mice, increased glucagon secretion concomitant to enhanced insulin secretion compared to C57BL/6 islets (unpublished results). The slight hyperglucagonemia might be due to an endocrine imbalance at the islet level or in the periphery. On the one hand, cytokines, such as interleukin 1, produced by the primary periislet infiltrating cells, are known to stimulate glucagon secretion in vivo and in vitro (34-36). On the other hand, because insulin is known to affect glucagon secretion (37-39), the $\alpha$-cell disturbance might be primary or secondary to $\beta$-cell abnormalities and/or insulin signaling. Conversely, because glucagon is known to stimulate insulin secretion
(40-43), it cannot be excluded that the relative hyperglucagonemia after weaning might be partly responsible for the basal hyperinsulinemia that we previously observed, particularly in NOD females, from 4 weeks of age onward (2). Such a sequence of events has already been described in C57BL/Ks mice, a spontaneous model of type II diabetes (41). Finally, after weaning, glucagon-like peptide 1 (GLP-1), a product of postprandial glucagon processing, may also play a role in insulin secretion and/or action (44). In this context, plasma GLP-1 levels were found to be doubled in diabetes-prone $B B$ rats than in nondiabetes-prone rats (45), and GLP1 is able to modulate insulin binding (44).

After weaning, NOD and NODscid mice, compared to C57BL/6 mice, had low basal glycemia, in relationship with their respective strong hyperinsulinemia $(2,5)$, accompanied by very mild hyperglucagonemia. These data underline a state of islet hyperactivity in postweaned NOD strains. This finding may be partly associated with the high percentages of adult $\beta$ stem cells $\left(\mathrm{SOM}^{+} / \mathrm{PDXI}^{+}\right)$observed after weaning in NOD mice (9). Moreover, hyperactive islets may be essential for the progression of the disease in the NOD mouse, because they are known to express elevated levels of cell adhesion ligands, major histocompatibility complex molecules, and autoantigens, which may heighten the sensitivity of $\beta$ cells to the cytotoxic effects of cytokines (4). NODscid mice, however, despite the existence of both islet hyperactivity and antigen-presenting cell infiltration, would not progress through insulitis and diabetes, because of their lack of functional lymphocytes.

In conclusion, endocrine disturbances including $\beta$-cell hyperactivity (8) associated with the presence of immature islets, possibly reflecting islet neogenesis, and deficient $\alpha$-cell function, are present at the islet level in NOD mice during the early neonatal period. Other investigators have described increased islet $\beta$-cell apoptosis in NOD mice from birth onward (46), which could be a consequence of neonatal $\beta$-cell hyperactivity. The causes of these disturbances remain to be determined; they may involve genetic, maternal, and/or fetal factors. These disturbances may cause or stem from $\beta$-cell dysfunction, resulting in increased $\beta$-cell sensitivity or even targeting of the autoimmune reaction.

\section{Acknowledgments}

C.P. had a fellowship from the "Subprograma de Perfeccionamiento para Doctores y Tecnólogos en el Extranjero" of the Dirección General de Investigación Científica y Ensenanza Superior (Ministerio de Educación y Cultura, Spain). Work from UMR 8603 was supported by grants from CNRS, University of Paris V, INSERM-NWO, Alfediam (associated with Lilly Laboratories) and BIOMED ("Betimmune"). 
The authors wish to thank Dr. P. Leenen for useful discussions and Dr. Jordi Vilaplana for his advice on the statistical analyses of the data. We also thank Isabelle Cissé for technical assistance.

\section{References}

1. Gonzalez A, Katz JD, Mattei MG, Kikutani H, Benoist C, Mathis D. (1997) Genetic control of diabetes progression. Immunity 7: 873-883.

2. Bach JF. (1994) Insulin-dependent diabetes mellitus as an autoimmune disease. Endocr. Rev. 15: 516-542.

3. Rossini AA, Handler ES, Mordes JP, Greiner DL. (1995) Animal models of human disease. Human autoimmune diabetes mellitus: lessons from BB rats and NOD micecaveat emptor. Clin. Immunol. Immunopathol. 74: 2-9

4. Homo-Delarche F, Boitard C. (1996) Autoimmune diabetes: the role of the islets of Langerhans. Immunol. Today 17: 456-460.

5. Homo-Delarche F. (1997) Beta-cell behaviour during the prediabetic stage. Part II. Non-insulin-dependent and insulindependent diabetes mellitus. Diabetes. Metab. 23: 473-505.

6. Amrani A, Durant S, Throsby M, Coulaud J, Dardenne M, Homo-Delarche F. (1998) Glucose homeostasis in the nonobese diabetic mouse at the prediabetic stage. Endocrinology 139: 1115-1124.

7. Pelegri C, Throsby M, Durant S, et al. (1999) Anomalies des cellules $\beta$ et $\alpha$ chez la souris nonobese diabetic (NOD) en période post-natale précoce. Diabetes Metab. 25(suppl 1): 24 Abs

8. Prochazka M, Gaskins HR, Schulz LD, Leiter EH. (1992) The nonobese diabetic scid mouse: model for spontaneous thymomagenesis associated with immunodeficiency. Proc. Natl. Acad. Sci. U.S.A. 89: 3290-3294.

9. Fernandes CA, King LC, Guz Y, Stein R, Wright CV, Teitelman G. (1997) Differentiation of new insulin-producing cells is induced by injury in adult pancreatic islets. Endocrinology 138: $1750-1762$.

10. Jansen A, Homo-Delarche F, Hooijkaas H, Leenen PJ, Dardenne M, Drexhage HA. (1994) Immunohistochemical characterization of monocytes-macrophages and dendritic cells involved in the initiation of the insulitis and beta-cell destruction in NOD mice. Diabetes 43: 667-675.

11. Rosmalen JGM, Martin T, Dobbs C, et al. (2000) Subsets of macrophages and dendritic cells in nonobese diabetic mouse pancreatic inflammatory infiltrates: correlation with the development of diabetes. Lab Invest 80: 23-30.

12. McEvoy RC, Madson KL. (1980) Pancreatic insulin-, glucagon-, and somatostatin-positive islet cell populations during the perinatal development of the rat. a. Morphometric quantitation. Biol. Neonate 38: 248-254.

13. McEvoy RC, Madson KL. (1980) Pancreatic insulin-, glucagon-, and somatostatin-positive islet cell populations during the perinatal development of the rat. b. Changes in hormone content and concentration. Biol. Neonate 38: 255-259.

14. Girard J, Bal D, Assan R. (1972) Glucagon secretion during the early postnatal period in the rat. Horm. Metab. Res. 4: 168-170.

15. Girard J, Cuendet GS, Marliss EB, Kervran A, Rieutort M, Assan R. (1973) Fuels, hormones, and liver metabolism at term and during the early postnatal period in the rat. J. Clin. Invest. 52: 3190-3200.

16. Rosselin G, Emami S. (1997) Growth and differentiation of the islet cells in neonates. In: Pancreatic growth and regeneration. Karger Landes Systems, Basel, Switzerland, pp. 44-95.

17. Jin SL, Hynes MA, Simmons JG, Lauder JM, Lund PK. (1992) Ontogeny of glucagon messenger RNA in the rat pancreas. Histochemistry 97: 431-438.

18. Bottazzo GF, Lendrum R. (1976) Separate autoantibodies to human pancreatic glucagon and somatostatin cells. Lancet I: 873-876.

19. Durinovic-Bello I, Hummel M, Ziegler AG. (1996) Cellular immune response to diverse islet cell antigens in IDDM. Diabetes 45: 795-800.
20. Schopfer K, Matter L, Tenschert R, Bauer S, Zuppinger K. (1984) Anti-glucagon-cell and anti-adrenal-medullary-cell antibodies in islet-cell-autoantibody-positive diabetic children. N. Engl. J. Med. 310: 1536-1537.

21. Semakula C, Vandewalle CL, Van Schravendijk CFH, et al. (1996) Abnormal circulating pancreatic enzyme activities in more than twenty-five percent of recent-onset insulindependent diabetic patients: association of hyperlipasemia with high-titer islet cell antibodies. Pancreas 12: 321-333.

22. Rosmalen JG, Homo-Delarche F, Durant S, Kap M, Leenen PJM, Drexhage HA. (1996) Islet abnormalities associated with an early influx of dendritic cells and macrophages in NOD and NODscid mice. Lab. Invest. 80: 769-777.

23. Fitzpatrick F, Lepault F, Homo-Delarche F, Bach JF, Dardenne M. (1991) Influence of castration, alone or combined with thymectomy, on the development of diabetes in the nonobese diabetic mouse. Endocrinology 129: 1382-1390.

24. Amrani A, Chaouloff F, Mormede P, Dardenne M, HomoDelarche F. (1994) Glucose, insulin and open-field responses to immobilization in nonobese diabetic (NOD) mice. Physiol. Behav. 56: 241-246.

25. Bonnevie-Nielsen V. (1980) Experimental diets affect pancreatic insulin and glucagon differently in male and female mice. Metabolism 29: 386-391.

26. Tomita T, Doull V, Fredrickson D, Pollock G. (1990) Pancreatic polypeptide and other pancreatic hormones in spontaneously diabetic BB/W rats. Pancreas 5: 658-667.

27. Pictet RL, Clark WR, Williams RH, Rutter WJ. (1972) An ultrastructural analysis of the developing embryonic pancreas. Dev. Biol. 29: 436-467.

28. Ferrand N, Astesano A, Phan HH, Lelong C, Rosselin G. (1995) Dynamics of pancreatic cell growth and differentiation during diabetes reversion in STZ-treated newborn rats. Am. J. Physiol. 269: 1250-1264.

29. Gu D, Sarvetnick N. (1993) Epithelial cell proliferation and islet neogenesis in IFN-gamma transgenic mice. Development 118: $33-46$.

30. Rall LB, Pictet RL, Williams RH, Rutter WJ. (1973) Early differentiation of glucagon-producing cells in embryonic pancreas: a possible developmental role for glucagon. Proc. Natl. Acad. Sci. U.S.A. 70: 3478-3482.

31. Zeidler A, Tosco C, Kumar D, Slavin B, Parker J. (1982) Spontaneous hyperglycemia and impaired glucose tolerance in athymic nude BALB/c mice. Diabetes 31: 821-825.

32. Zeidler A, Shargill NS, Chan TM. (1991) Peripheral insulin insensitivity in the hyperglycemic athymic nude mouse: similarity to noninsulin-dependent diabetes mellitus. Proc. Soc. Exp. Biol. Med. 196: 457-460.

33. Ohneda A, Kobayashi T, Nihei J, Tochino Y, Kanaya H, Makino S. (1984) Insulin and glucagon in spontaneously diabetic non-obese mice. Diabetologia 27: 460-463.

34. Heindorff $H$, Almdal T, Vilstrup H. (1994) The in vivo effect of interleukin- $1 \beta$ on urea synthesis is mediated by glucocorticoids in rats. Eur. J. Clin. Invest. 24: 388-392.

35. Wogensen LD, Kolb-Bachofen V, Christensen P, et al. (1990) Functional and morphological effects of interleukin 1 beta on the perfused rat pancreas. Diabetologia 33: 15-23.

36. Zumsteg U, Reimers JI, Pociot F, et al. (1993) Differential interleukin-1 receptor antagonism on pancreatic beta and alpha cells. Studies in rodent and human islets and in normal rats. Diabetologia 36: 759-766.

37. Greenbaum CJ, Havel PJ, Taborsky GJ, Klaff LJ. (1991) Intraislet insulin permits glucose to directly suppress pancreatic A cell function. J. Clin. Invest. 88: 767-773.

38. Dumonteil E, Magnan C, Ritz-Laser B, et al. (1998) Insulin, but not glucose lowering corrects the hyperglucagonemia and increased proglucagon messenger ribonucleic acid levels observed in insulinopenic diabetes. Endocrinology 139: $4540-4546$.

39. Kaneko K, Shirotani T, Araki E, et al. (1999) Insulin inhibits glucagon secretion by the activation of PI3-kinase in In-R 1G9 cells. Diabetes Res. Clin. Pract. 44: 83-92. 
40. Laube H, Fussganger RD, Maier V, Pfeiffer EF. (1973) Hyperglucagonemia of the isolated perfused pancreas of diabetic mice (db/db). Diabetologia 9: 400-402.

41. Leiter EH, Coleman DL, Eppig JJ. (1979) Endocrine pancreatic cells of postnatal "diabetes" $(\mathrm{db})$ mice in cell culture. In Vitro Cell Dev. Biol. 15: 507-521.

42. Vecchio D, Luyckx A, Zahnd GR, Renold AE. (1966) Insulin release induced by glucagon in organ cultures of fetal rat pancreas. Metab. Clin. Exp. 15: 577-581.

43. Kawai K, Yokota C, Ohashi S, Watanabe Y, Yamishita K. (1995) Evidence that glucagon stimulates insulin secretion through its own receptor in rats. Diabetologia 38: 274-276.
44. Ebinger M, Jehle DR, Fussgaenger RD, Fehmann HC, Jehle PM. (2000) Glucagon-like peptide 1 improves insulin and proinsulin binding on RINm5F cells and human monocytes. Am. J. Physiol. Endocrinol. Metab. 279: E88-E94.

45. Reimer RA, Field CJ, McBurney MI. (1997) Ontogenic changes in proglucagon mRNA in BB diabetes-prone and normal rats weaned onto a chow diet. Diabetologia 40: 871-878.

46. Trudeau JD, Dutz JP, Arany E, Hill DJ, Fieldus WE, Finegood DT. (2000) Neonatal ß-cell apoptosis. A trigger for autoimmune diabetes? Diabetes 49: 1-7. 